
SPOUDAI
Journal of Economics and Business
$\sum \pi 0 v \delta \alpha i$
University
of Piraeus
http://spoudai.unipi.gr

\title{
Cross-sectional Analysis of Stock Returns in Athens Stock Exchange for the Period 2004-2011
}

\author{
Argiro Svingou \\ Department of Business Administration, University of Patras, Rio, 265 00, Greece, \\ Email: argirosv@yahoo.gr
}

\begin{abstract}
This study is an investigation of the factors affecting the average returns of stocks that were traded on the Athens Stock Exchange for the period July 2004 - June 2011. The methodological approach is similar to that applied by Fama and French (1992), in the first stage, stocks are grouped into portfolios with predefined criteria, and subsequently monthly cross sectional regressions are carried out, according to the Fama-MacBeth approach (1973). The main result of this study is that average stock returns in the ASE are not associated with the market beta (market risk) and there is not a strong relationship with any other risk factor for the stocks market value or book to market ratio.
\end{abstract}

JEL Classifications: G10, G11, G14.

Keywords: Cross-sectional analysis, Market beta, Size effect.

\section{Introduction}

Empirical results of a considerable amount of studies question the traditional view that the market beta suffice to explain the stock returns and propose some other factors related to firm-specific variables. However, the empirical research mainly concerns the USA and other development markets. One important issue is related to the generalization of the results. Is it correct to generalize the results to markets of different size and regulations?

The view that firm-specific variables, such as market value (size) or book to market ratio, have more explanatory power for the cross-section stock returns than market beta have caused arguments on the underlying rationale. As a result 
of the empirical research two views are held. The first one regards the existence of other risk factors that are related to these variables (Fama and French, 1992). The other one suggests these variables as measures or characteristics in which investors can recognize opportunities for excess returns (Daniel and Titman, 1997). Additionally, there is a discussion about the bias of methodology that is associated with data snooping bias (Kothari, Shanken and Sloan, 1995) and the sample period effect (Black 1993, Macknlay 1995).

This study contributes another piece to the puzzle investigating the role of some firm-specific variables and the explanatory power of the market beta in a small/emerging market, such as the Athens Stock Exchange. Compared to previous research that has pointed out the firm size effect in the Athens Stock Exchange, this study covers the recent time period 2004-2011 in order to examine whether this effect persists in the coming period or not. The investigating time period is crucial for ASE because the Greek economy experienced many and important structural changes, due to its introduction to euro zone in 2002.

Apart from market beta, we have chosen to study specific variables, such as size and book to market ratio, which have already been under empirical research in both developed markets and the ASE, as to be able to compare the findings. Our approach has focused on variables whose contribution in stock returns has been shown in developed markets while they could reasonably be considered to play a role in shaping the expectations of investors. The methodological approach is similar to that applied by Fama and French (1992). In the first stage, stocks are grouped into portfolios with predefined criteria, and subsequently monthly cross sectional regressions are carried out, according to the Fama-MacBeth approach (1973). The evidence of this study has shown that market beta is not sufficient to explain the cross-sectional average stock returns while we did not address size effect or any other effect.

The structure of this paper is as follows. In section 2 previous literature results are presented. In section 3 the data used and some preliminary statistic described. Methodology is presented in section 4. In section 5, the results of the study is presented and analyzed. Conclusions are in the section 6.

\section{Literature review}

In the early 80s, several studies identified deviations on the linear relationship between risk and returns that CAPM features, due to some other factors. The Capital Assets Pricing Model (CAPM) assume two simple hypotheses: a) the expected returns on assets are satisfactorily explained by market risk, and b) between returns and market beta there is a positive linear relationship. However, the results of direct tests have been inconclusive, because they pointed out de- 
viations from $\mathrm{CAPM}^{1}$, indicating the existence of additional factors, which are relevant to asset pricing. The empirical research has driven on the examination of some firm-specific variables, which have more explanatory power for the crosssection average stock returns than the traditional measures of risk, such as market beta.

Banz (1981) studied the NYSE-listed companies for the period 1926-1975 and concluded that the average stock returns with small market value were higher than the average return on stocks with high market value. This phenomenon was described as the "size effect". Banz argued that the size effect is not linear and is stronger for the smallest firms and this effect is due to the investors' behavior that does not want to retain small stocks because of insufficient information, leading so to higher returns. Also, Reinganum (1981) analyzed the size effect in a sample of 566 NYSE and Amex firms over the period 1963-1977 and he found the same results.

Bhandari (1988) argued that between leverage and average stock returns there is a positive linear relationship. More specifically, high leverage increases a firm's equity risk, but this increased risk should be reflected in a higher beta coefficient. However, Bhandari provided evidence that leverage helps explain the average stock returns having included in the model the market value and the market beta. Subsequently, he supported that if leverage is just a proxy for risk, a measure of risk different from beta must be found or the relation between risk and expected return perhaps is not linear.

Rosenberg, Reid and Lanstein (1985) studied the U.S. market and showed that average stock returns are positively related to the book to market ratio (BE/ME). They explained that this result is due to the fact that the prices on NYSE are inefficient. Also Chan, Hamao \& Lakonishok (1991), advocated that the book to market ratio $(\mathrm{BE} / \mathrm{ME})$ has a strong explanatory power for the cross-section average stock returns in Japan. They interpreted that this relation would be the result of a noise in reported earnings related to Japanese accounting standards.

Litzenberger and Ramaswamy (1979) showed that there is a strong positive relationship between stock returns and dividend yield for NYSE stocks. They argued that investors with higher tax brackets choose stocks with low dividend yields, and vice versa (clientele effect). So, the tax policy is what affects the investor's behavior to prefer or not stocks with low or high dividend yield.

Fama and French (1992), contented that size (market value) and book to market ratio $(\mathrm{BE} / \mathrm{ME})$ are two variables with strong explanatory power to average returns while they questioned the effect of market beta on average stock returns. They supported that if assets are priced rationally, their results show that stock risks are multidimensional, and one dimension of risk is proxied by size and the other by book to market ratio. 
The existence of a value effect (book to market ratio) tested for the previous and subsequent time period of the original Fama and French (1992) paper and the evidence shows that the effect of value also existed. Davis, Fama and French (2000) found that the premium associated with book to market ratio existed in the period 1929-1963. Also, Fama and French (1998) have shown that the value effect exists in a sample covering 13 countries (including the U.S.) over the period 1975-1995.

Knez and Ready (1997) demonstrated that the negative relation between average returns and firm size is driven by a few extreme sample observations. Merton (1978), Hou and Moskowitz (2005), supported that size effect can originate from incomplete information and linked it with the market frictions that were associated with the investors' recognition.

On the other hand, Hou, Korolui and Kho (2011) showed no reliable relation between stock returns and firm size using monthly returns for over 27,000 stocks from 49 countries, for the period 1981-2003. Downs and Ingram (2000) reached the same conclusion analyzing all NYSE stocks for the period 1963-1990 and additionally pointed out that market beta and stock returns are related positively.

Leledakis et al. (2003) found a strong size effect in the period July 1990 - June 2000 for the Athens Stock Exchange. Also, they supported that market beta lacks the power to explain stock returns. Glezakos and Milonas (2004) found the same results for the same period.

In this study, it was investigated whether this effect persists in the coming period (July 2004-June 2011). As of 2003, the companies listed in the Athens Stock Exchange, adopted the International Accounting Standards according to the Law 2992/2002. Therefore, the period July 2000-June 2004 was intentionally exempted so as to achieve accounting data comparability and compatibility. Also, we have chosen to examine variables for which empirical evidence has shown that between them there are overlapping effects. For example, Fama and French (1992) pointed out that the leverage and the book to market ratio essentially consists of two equivalent forms in order to explain the "book to market effect". Moreover, we tried to find whether the sales to price ratio is a stronger predictor than size and book to market ratio. Leledakis et al. (2001), showed evidence from the London Stock Exchange and indicated that the sales to price ratio has significant explanatory power on cross sectional stock returns and this effect is independent from the book to market ratio and the firm size. The effect of sales to price ratio was also indicated from Barbee et al. (1996), who had shown that the ratio of sales to price is better predictors of average equity returns than book to market ratio and firm size. 


\section{Description of the data}

Our data covers the period from July 2004 to June 2011 and relates to nonfinancial companies whose stocks are traded on the Athens Stock Exchange (ASE) for this period. Stocks of which it is not possible to find all the necessary data for the whole period, are not included in the sample. The final sample consists of stocks that are traded throughout the whole reporting period in order to eliminate survivorship bias. The final sample is composed from 149 out of the total 255 stocks. It represents the $59 \%$ of the total number of stocks and the $60 \%$ of the total number of non-financial companies. The daily close prices of stocks are collected from the electronic database www.4trader.net and they are used in order to calculate the monthly continuous compounding returns ${ }^{2}$. The calculation of monthly returns derives from the average of the daily returns of each month.

The accounting data are collected from the electronic database Thomson Reuters. We match the accounting data with the monthly stock returns after six months. Namely, the accounting data of year $\mathrm{t}-1$ are matched with the monthly stock returns from July $t$ to June $t+1$ (Fama and French, 1992). The traded companies' financial statements must be published at least 20 days before the annual stakeholder's convention, which takes place within six months after the end of each financial year. Matching the accounting data of the year $\mathrm{t}-1$ with the monthly returns from July $t$ to June $t+1$ ensures the information availability to the public.

Our approach focuses on variables whose contribution in stock returns has been shown in developed markets while they could reasonably be considered to play a role in shaping the expectations of investors. These variables are the following:

- $\mathrm{ME}=$ Market value of the equity of the firm. We determine market value at the end of December of year $\mathrm{t}-1$ in order to compute accounting variables and market value at the end of June of year $t$ to measure its size.

- $\mathrm{BE} / \mathrm{ME}=$ Book to market ratio at the end of December in year $\mathrm{t}-1$.

- $\mathrm{A} / \mathrm{ME}=$ The ratio between the book value of total assets of a firm and the firm's market value of equity, at the end of December in year t- 1 .

- $\mathrm{A} / \mathrm{BE}=$ The ratio between the book value of total assets of a firm and the firm's book value of equity, at the end of December in year t-1.

- $\mathrm{DY}=$ The dividend yield is calculated as the ratio of the dividend of a firm the financial year-end in year $\mathrm{t}-1$ and the firms market value of equity at the end of December in year $\mathrm{t}-1$.

- $\mathrm{S} / \mathrm{P}=$ Sales to price ratio, at the end of December in year $\mathrm{t}-1$.

- $\beta=$ The individual company's market beta.

In order to avoid the error of outliers in regressions the smallest and the largest $1 \%$ of the values for $\mathrm{BE} / \mathrm{ME}, \mathrm{A} / \mathrm{ME}, \mathrm{A} / \mathrm{BE}, \mathrm{S} / \mathrm{P} \& \mathrm{DY}$, are set equal to the next smallest and the next largest value of the ratios. 
The variables $\mathrm{ME}, \mathrm{BE} / \mathrm{ME}, \mathrm{A} / \mathrm{ME}, \mathrm{A} / \mathrm{BE}$ and $\mathrm{S} / \mathrm{P}$ are transformed in natural logarithm (Fama and French, 1992). The transformation of the variable DY is not possible because it can take zero prices.

Table 1 presents the summary statistics of the time series for each variable, as derived from the 149 stocks for the period July 2004 - June 2011.

Table 1

Summary Statistics

\begin{tabular}{|c|c|c|c|}
\hline Variables & \multicolumn{1}{|c|}{ Mean } & \multicolumn{1}{c|}{ Median } & Std. Dev. \\
\hline Market beta $(\beta)$ & 1.1087 & 1.0557 & 0.5315 \\
\hline Market value of equity - ME & 17.7163 & 17.4952 & 1.6939 \\
\hline Book to market equity - Ln(BE/ME) & 0.0055 & -0.0152 & 1.0149 \\
\hline Market leverage - Ln(A/ME) & 0.9280 & 0.8063 & 1.0579 \\
\hline Book leverage - Ln(A/BE) & 0.9222 & 0.8871 & 0.5068 \\
\hline Dividend yield - D/Y & 0.0193 & 0.0051 & 0.0399 \\
\hline Sales to price -Ln(S/P) & 0.4292 & 0.4559 & 1.2042 \\
\hline
\end{tabular}

\section{Methodology}

The methodology followed in this study was based on that of Fama and French (1992). The first approach refers to the portfolio grouping, in which at the end of June of each year, all stocks were sorted into five portfolios. Each portfolio included thirty stocks except for the last (the largest), which contained twenty nine stocks. We estimated the return of each portfolio per month as the simple average of the monthly stock returns that this contained. The monthly returns of each portfolio were recorded and the result was an average return for each portfolio, for the whole period.

Following, we applied the Fama and MacBeth regression (1973), in order to measure the return premiums related to the company-specific variables and market beta. The methodology procedure was conducted in two steps. In the first step, the market beta of each company was estimated, from time-series regressions using data up to the period ( $\mathrm{t}-1)$. More specifically, the market beta of each firm was estimated from the market model $R_{i t}=a+\beta_{i} \mathrm{R}_{\mathrm{mt}}+e_{i t}$. It was estimated by OLS using 30 to 60 prior monthly returns, ending in June in year $t$ while the general index was used as an approach of market $\left(\mathrm{R}_{\mathrm{m}}\right)$. The process was repeated for each year of the sample period. 
In the second step, at each period $\mathrm{t}$, a cross-sectional regression was being run and a time series of estimators was obtained. In particular, in each month of the sample period we ran a (ordinary least square) cross-section regression of stock returns on market beta and other firm-specific variables. We run these regressions using the returns of individual stocks ${ }^{3}$. We calculated the average, from the time series obtained, for each variable coefficients and the constant term. The time-series average from each series of variables was used as the coefficient of the relative variable. The statistical significance of the coefficients was made by the t-statistic, against a null value of zero. The value of t-statistic was calculated by dividing the average coefficient by its time-series standard error.

According to Fama and MacBeth (1973) ${ }^{4}$ the monthly repeating procedure helps us to avoid the downward bias of the cross-sectional regressions error terms. Especially, in each (ordinary least squares) cross sectional regression it is probable that the error terms are cross sectional correlated and heteroscedastic ${ }^{5}$. In this case, the value of t- statistic in the individual (ordinary least squares) crosssectional regression tends to overstate the precision of the estimated parameter's actual significance. In order to eliminate this problem, Fama and MacBeth (1973) ran cross-sectional regressions each month, generating time series for each parameter estimates. Moreover, this process uses only time-series standard errors to calculate the t-statistic and not that from each individual cross-sectional regression. Finally, with the cross-sectional regression method, it is rather straightforward to interpret the results in economic terms. It is also convenient to examine model misspecification by checking whether firm characteristics such as relative size and book-to-market value explain any residual variation in average returns across firms.

\section{Results}

\subsection{Portfolios Grouping}

Table 2 shows the results for our sample of stocks in their classification into portfolios. The returns are the average of 84 monthly portfolio returns from July 2004 to June 2011. The values of the other variables are also the average annual rates for each portfolio.

Panel A of Table 2 shows the averages of the 84 monthly returns of five portfolios that have been created by using the market beta as classification criterion. The portfolio "small $\beta$ " includes 30 stocks (out of the 149 stocks of the total sample), which have the smallest $\beta$ while the portfolio "Large $\beta$ " contains 29 stocks, which have the highest values of $\beta$. As we move towards portfolios which include stocks with larger values $\beta$, returns are lessened. The negative relationship bet- 
ween returns and the market beta had shown Leledakis et al. (2003) in their study of the ASE during the period 1990-2000 in the same test. The negative relationship between stock returns and market beta does not confirm the model's prediction proposed by Sharpe - Lintner - Black, known as SLB Model, according to which high risk securities or assets (i.e. high $\beta$ ) give higher returns.

\section{Table 2}

Properties of portfolios formed on market beta $(\beta)$, market value of equity, book to market ratio, market leverage, book leverage, sales to price ratio and dividend yield: July 2004 to June 2011

\begin{tabular}{|c|c|c|c|c|c|c|c|c|}
\hline & Return \% & Beta & Ln (ME) & Ln(BE/ME) & Ln(A/ME) & Ln(A/BE) & DY & Ln (S/P) \\
\hline Panel A: Portfolios Formed on coefficient beta \\
\hline Small $\beta$ & $-0.045 \%$ & 0.444 & 18.007 & -0.441 & 0.358 & 0.799 & 0.020 & -0.108 \\
\hline$\beta 2$ & $-0.064 \%$ & 0.846 & 17.903 & -0.147 & 0.767 & 0.913 & 0.022 & 0.364 \\
\hline$\beta 3$ & $-0.058 \%$ & 1.090 & 17.679 & 0.088 & 1.005 & 0.917 & 0.025 & 0.533 \\
\hline$\beta 4$ & $-0.051 \%$ & 1.347 & 17.664 & 0.296 & 1.143 & 0.901 & 0.015 & 0.542 \\
\hline Large $\beta$ & $-0.070 \%$ & 1.787 & 17.309 & 0.317 & 1.392 & 1.075 & 0.015 & 0.860 \\
\hline Panel B: Portfolios Formed on Market Value of Equity \\
\hline Small ME & $-0.054 \%$ & 1.254 & 15.651 & 0.839 & 1.665 & 0.880 & 0.014 & 1.066 \\
\hline ME 2 & $-0.046 \%$ & 1.096 & 16.711 & 0.261 & 1.044 & 0.783 & 0.026 & 0.517 \\
\hline ME 3 & $-0.077 \%$ & 1.157 & 17.483 & 0.071 & 1.119 & 1.048 & 0.016 & 0.672 \\
\hline ME 4 & $-0.078 \%$ & 1.055 & 18.470 & -0.263 & 0.699 & 0.962 & 0.017 & 0.156 \\
\hline Large ME & $-0.039 \%$ & 0.972 & 20.223 & -0.780 & 0.154 & 0.935 & 0.024 & -0.200 \\
\hline Panel C: Portfolios Formed on Book to Market Value of Equity & \\
\hline Small BE/ME & $-0.067 \%$ & 0.877 & 19.167 & -1.296 & -0.212 & 1.084 & 0.020 & -0.513 \\
\hline BE/ME 2 & $-0.084 \%$ & 1.010 & 18.280 & -0.400 & 0.559 & 0.959 & 0.017 & 0.122 \\
\hline BE/ME 3 & $-0.069 \%$ & 1.157 & 17.671 & 0.016 & 0.927 & 0.911 & 0.021 & 0.469 \\
\hline BE/ME 4 & $-0.036 \%$ & 1.203 & 17.155 & 0.424 & 1.248 & 0.825 & 0.021 & 0.702 \\
\hline Large BE/ME & $-0.036 \%$ & 1.284 & 16.358 & 1.329 & 2.114 & 0.839 & 0.018 & 1.390 \\
\hline Panel D: Portfolios Formed on Market Leverage \\
\hline Small A/ME & $-0.073 \%$ & 0.836 & 19.086 & -1.113 & -0.359 & 0.754 & 0.018 & -0.776 \\
\hline A/ME 2 & $-0.058 \%$ & 0.970 & 18.168 & -0.322 & 0.438 & 0.759 & 0.022 & 0.026 \\
\hline A/ME 3 & $-0.060 \%$ & 1.148 & 17.543 & 0.005 & 0.889 & 0.884 & 0.023 & 0.393 \\
\hline A/ME 4 & $-0.045 \%$ & 1.249 & 17.231 & 0.366 & 1.373 & 1.007 & 0.017 & 0.884 \\
\hline
\end{tabular}

(to be continued) 


\begin{tabular}{|c|c|c|c|c|c|c|c|c|}
\hline Large $\mathrm{A} / \mathrm{ME}$ & $-0.057 \%$ & 1.328 & 16.599 & 1.147 & 2.301 & 1.208 & 0.015 & 1.641 \\
\hline \multicolumn{9}{|c|}{ Panel E: Portfolios Formed on Book Leverage } \\
\hline Small A/BE & $-0.040 \%$ & 1.044 & 17.145 & 0.195 & 0.509 & 0.313 & 0.020 & -0.250 \\
\hline $\mathrm{A} / \mathrm{BE} 2$ & $-0.052 \%$ & 1.020 & 17.889 & 0.091 & 0.703 & 0.611 & 0.025 & 0.213 \\
\hline $\mathrm{A} / \mathrm{BE} 3$ & $-0.048 \%$ & 1.087 & 17.917 & 0.113 & 0.989 & 0.876 & 0.016 & 0.479 \\
\hline $\mathrm{A} / \mathrm{BE} 4$ & $-0.074 \%$ & 1.182 & 17.863 & -0.021 & 1.107 & 1.128 & 0.021 & 0.692 \\
\hline Large $\mathrm{A} / \mathrm{BE}$ & $-0.081 \%$ & 1.198 & 17.726 & -0.266 & 1.354 & 1.674 & 0.015 & 1.048 \\
\hline \multicolumn{9}{|c|}{ Panel F: Portfolios Formed on Sales to Price } \\
\hline Small S/P & $-0.053 \%$ & 0.908 & 18.572 & -0.683 & -0.054 & 0.630 & 0.014 & -1.188 \\
\hline $\mathrm{S} / \mathrm{P} 2$ & $-0.065 \%$ & 1.076 & 18.371 & -0.327 & 0.496 & 0.823 & 0.020 & -0.044 \\
\hline $\mathrm{S} / \mathrm{P} 3$ & $-0.074 \%$ & 1.054 & 17.493 & -0.030 & 0.848 & 0.879 & 0.020 & 0.538 \\
\hline $\mathrm{S} / \mathrm{P} 4$ & $-0.051 \%$ & 1.158 & 17.281 & 0.302 & 1.293 & 0.991 & 0.020 & 0.977 \\
\hline Large $\mathrm{S} / \mathrm{P}$ & $-0.050 \%$ & 1.327 & 16.878 & 0.842 & 2.074 & 1.286 & 0.022 & 1.885 \\
\hline \multicolumn{9}{|c|}{ Panel G: Portfolios Formed on dividend Yield } \\
\hline Small DY & $-0.083 \%$ & 1.082 & 17.658 & -0.199 & 0.542 & 0.742 & 0.000 & -0.620 \\
\hline DY 2 & $-0.070 \%$ & 1.210 & 16.993 & 0.307 & 1.365 & 1.058 & 0.000 & 0.697 \\
\hline DY 3 & $-0.061 \%$ & 1.230 & 17.695 & 0.192 & 1.247 & 1.110 & 0.006 & 0.933 \\
\hline DY 4 & $-0.040 \%$ & 1.017 & 18.266 & -0.188 & 0.694 & 0.883 & 0.022 & 0.375 \\
\hline Large DY & $-0.044 \%$ & 0.992 & 17.953 & -0.002 & 0.809 & 0.810 & 0.067 & 0.789 \\
\hline
\end{tabular}

Note: In each panel the stocks are grouped into 5 portfolios by a different variable. Returns are the time-series average of 85 monthly portfolio returns, in percentage terms. Beta is the average of the $\beta$ of individual stocks in each portfolio, estimated by using 30 to 60 prior monthly returns. $\mathrm{Ln}(\mathrm{ME}), \ln (\mathrm{BE} / \mathrm{ME}), \ln (\mathrm{A} / \mathrm{ME}), \ln (\mathrm{A} / \mathrm{BE}), \mathrm{DY}$, and $\ln (\mathrm{S} / \mathrm{P})$ are the average of the annual values of these variables in each portfolio. The prefix $\ln ($.$) means that the variables$ are transformed in natural logarithm form.

Panel B of Table 2, presents the average returns of five portfolios created by using the market value equity (ME) as sorting criterion. The "small size" portfolio includes stocks with the smallest market value and the "large size" portfolio contains stocks with the largest market value. Returns increase from $-0.054 \%$ to $-0.039 \%$, an increase of $0.015 \%$ per month (or $0.18 \%$ annually). In the middle portfolios, we observe a downward trend in returns with increasing market value. Our results do not clearly show "size effect", it appears a little in the intermediate portfolios, while it is not detected between the two extremes. As for the relationship between market beta and average returns, our previous finding is being repeated. There is a negative relationship between average returns and market beta. Market beta is reduced from 1.254 to 0.972 while average returns move to the opposite direction between the two extreme portfolios. 
Panel $\mathrm{C}$ of Table 2, average returns are positively associated with book to market ratio (BE/ME). The average returns are increased by $0.031 \%$ per month (and $0.37 \%$ on an annual basis) as we move to higher BE / ME ratios. This speed of increase of the average returns is twice as large as the average returns of the portfolios ME, previously analyzed. It is important to note that relations implied through this methodology with both BE/ME and size (ME) do not compose a phenomenon that can be attributed to an indirect effect of the market beta. Table 2 , shows that the values of $\beta$ as in panel $B$ and in panel $C$ do not differ across portfolios in comparison to the range of $\beta$ in panel $\mathrm{A}$. In panel $\mathrm{B}$ and $\mathrm{C}$, betas have a range 0.282 and 0.408 respectively, while in panel $\mathrm{A}$ its range is 1.343.

In the next two panels ( $\mathrm{D}$ and $\mathrm{E}$ ), the average returns of portfolios are formed by sorting criterion the variables of leverage. Regarding the market leverage, as market leverage increases the average returns also increase (positive relationship). There is a $0.016 \%$ increase per month and $0.192 \%$ on an annual basis. Book leverage (A/BE) has the opposite effect on average returns, a negative relationship between returns and book leverage is observed. While each of these variables has an opposite effect on returns, more intense seems to be the effect of book leverage.

In panel $\mathrm{F}$ table, the variable under investigation is the sales to price ratio. We observe that the average returns on extreme portfolios do not have significant differences and are higher than those of the middle portfolios. Portfolios "small$\mathrm{S} / \mathrm{P}$ " and "large $\mathrm{S} / \mathrm{P}$ " give average returns of $0.022 \%$ higher than the medium portfolio "S/P 3".

Finally, in panel G, where sorting is based on dividend yield, the average returns seem to follow an upward trend as we move to higher divided yields, however, it is not clear. We observe that between portfolios "DY 4" and "large DY" the average returns are decreased.

The above results highlight some correlations between sub-test variables, which become even more evident from the correlation coefficients listed in the following table.

Table 3

Correlation Coefficients

\begin{tabular}{|c|r|r|r|r|r|r|}
\hline & \multicolumn{1}{|c|}{ BETA } & \multicolumn{1}{c|}{ ME } & \multicolumn{1}{c|}{ BE/ME } & A/ME & \multicolumn{1}{c|}{ A/BE } & \multicolumn{1}{c|}{ S/P } \\
\hline $\mathrm{ME}$ & -0.113 & & & & & \\
\hline $\mathrm{BE} / \mathrm{ME}$ & 0.139 & -0.614 & & & & \\
\hline $\mathrm{A} / \mathrm{ME}$ & 0.176 & -0.575 & 0.881 & & & \\
\hline $\mathrm{A} / \mathrm{BE}$ & 0.091 & 0.026 & -0.163 & 0.323 & & \\
\hline $\mathrm{S} / \mathrm{P}$ & 0.132 & -0.426 & 0.639 & 0.802 & 0.393 & \\
\hline $\mathrm{DY}$ & -0.036 & 0.055 & 0.033 & 0.001 & -0.063 & 0.122 \\
\hline
\end{tabular}


Most important is that the market value equity (ME) is negatively related to the ratio $\mathrm{BE} / \mathrm{ME}$ and market leverage. The ratio $\mathrm{BE} / \mathrm{ME}$ is positively related to market leverage and with the $\mathrm{S} / \mathrm{P}$ ratio. Also, there is a strong positive correlation between the $\mathrm{S} / \mathrm{P}$ ratio and the market leverage.

\subsection{Cross-Sectional Regression}

Table 4 presents the average coefficients (\%) from 84 monthly cross-sectional regressions of stock returns with different combinations of variables while in parenthesis are the t-statistics, against a null value of zero. The values of t-statistics are calculated by dividing the average coefficient by its time-series standard error.

Model A of Table 4 shows that the relation between stocks returns and market beta is not statistically significant, indicating that the market beta does not have explanatory power to average stock returns. Moreover, when the market beta is combined with the market value and the book to market ratio the results are the same, market beta remains a non statistical significant factor (Model G, H, and K). Fama and French (1992), Leledakis et al. (2003) have also indicated the failure of market beta in explaining the stock returns.

Model B of Table 4 investigated the "size effect", that does not seem to exist in this time period, in contrast to Leledakis et al. (2003), who pinpointed a strong size effect for the period 1990-2000 in ASE. Our results do not show statistical significance, the value of the average coefficient is $0.004 \%$, with a low t-statistic of 0.65 . Models G, I, J, L, where market value is combined with other explanatory variables, show the same result. However, when the market value is combined with the book to market ratio (Model K), we observe that size is marginally statistically significant.

In any case, we observe that the conclusion of Leledakis et al. (2003) about the size effect (ME), for the ASE covering the period 1990-2000 does not appear in our case to maintain the same statistical significance. We believe that these differences in results about size depend on the time period. It is perhaps due to the general economic conditions that characterize the two papers. 


\section{Table 4}

Average coefficients \% for regressions of stock returns with different combinations of variables July 2004 to June 2011 (t-statistics in parentheses)

\begin{tabular}{|c|c|c|c|c|c|c|c|c|c|}
\hline & $\gamma_{0}$ & B & In ME & $\begin{array}{c}\text { ln } \\
\text { BE/ME }\end{array}$ & $\begin{array}{c}\ln \\
\mathrm{A} / \mathrm{ME}\end{array}$ & $\begin{array}{c}\text { ln } \\
\mathbf{A} / \mathbf{B E}\end{array}$ & $\begin{array}{l}\text { In } \\
\text { S/P }\end{array}$ & DY & $\begin{array}{c}\text { Avg } \\
\mathbf{R}^{2}\end{array}$ \\
\hline (A) & $-0.046 \%$ & $-0.019 \%$ & & & & & & & 0.022 \\
\hline t-stat & $(-1.59)$ & $(-0.72)$ & & & & & & & \\
\hline (B) & $-0.131 \%$ & & $0.004 \%$ & & & & & & 0.021 \\
\hline t-stat & $(-1.09)$ & & $(0.65)$ & & & & & & \\
\hline (C) & $-0.059 \%$ & & & $0.013 \%$ & & & & & 0.017 \\
\hline t-stat & $(-1.43)$ & & & $(1.31)$ & & & & & \\
\hline (D) & $-0.031 \%$ & & & & $0.011 \%$ & $-0.040 \%$ & & & 0.031 \\
\hline t-stat & $(-0.82)$ & & & & (0.99) & $(-2.78)$ & & & \\
\hline (E) & $-0.060 \%$ & & & & & & $0.001 \%$ & & 0.016 \\
\hline t-stat & $(-1.50)$ & & & & & & $(0.09)$ & & \\
\hline$(\mathrm{F})$ & $-0.064 \%$ & & & & & & & $0.207 \%$ & 0.008 \\
\hline t-stat & $(-1.50)$ & & & & & & & $(0.06)$ & \\
\hline (G) & $-0.147 \%$ & $-0.013 \%$ & $0.005 \%$ & & & & & & 0.042 \\
\hline t-stat & $(-1.26)$ & $(-0.47)$ & $(0.86)$ & & & & & & \\
\hline$(\mathrm{H})$ & $-0.038 \%$ & $-0.025 \%$ & & $0.016 \%$ & & & & & 0.036 \\
\hline t-stat & $(-1.33)$ & $(-0.94)$ & & $(1.65)$ & & & & & \\
\hline (I) & $-0.258 \%$ & & $0.011 \%$ & $0.021 \%$ & & & & & 0.034 \\
\hline t-stat & $(-2.13)$ & & $(1.73)$ & $(2.01)$ & & & & & \\
\hline$(\mathrm{J})$ & $-0.199 \%$ & & $0.012 \%$ & & $0.016 \%$ & $-0.047 \%$ & & & 0.048 \\
\hline t-stat & $(-1.65)$ & & $(1.71)$ & & $(1.38)$ & $(-3.14)$ & & & \\
\hline$(\mathrm{K})$ & $-0.273 \%$ & $-0.023 \%$ & $0.013 \%$ & $0.025 \%$ & & & & & 0.051 \\
\hline t-stat & $(-2.29)$ & $(-0.87)$ & $(2.05)$ & $(2.54)$ & & & & & \\
\hline (L) & $-0.248 \%$ & & $0.011 \%$ & $0.026 \%$ & & & $-0.008 \%$ & & 0.048 \\
\hline t-stat & $(-2.05)$ & & $(1.65)$ & $(2.50)$ & & & $(-1.07)$ & & \\
\hline
\end{tabular}

Note: The average coefficient (in percentage) is the time-series average of the 85 monthly regressions coefficients for July 2004 to June 2011. T-statistic is the average coefficient 
divided by its time-series standard error. The values of t-statistics are in parentheses. The cross-sectional regressions conducted, concern the following models:
(A) Rit $=\gamma_{0 \mathrm{t}}+\gamma_{1 \mathrm{t}} \beta_{\mathrm{it}}+\varepsilon_{\mathrm{it}}$
(B) $R i t=\gamma_{0 \mathrm{t}}+\gamma_{1 \mathrm{t}} \mathrm{LnME}_{\mathrm{it}}+\varepsilon_{\mathrm{it}}$
(C) $R i t=\gamma_{0 \mathrm{t}}+\gamma_{1 \mathrm{t}} \operatorname{Ln}(\mathrm{BE} / \mathrm{ME})_{\mathrm{it}}+\varepsilon_{\mathrm{it}}$
(D) $R i t=\gamma_{0 \mathrm{t}}+\gamma_{1 \mathrm{t}} \operatorname{Ln}(\mathrm{A} / \mathrm{ME})_{\mathrm{it}}+\gamma_{2 \mathrm{t}} \operatorname{Ln}(A / B E)_{\mathrm{it}}+\varepsilon_{\mathrm{it}}$
(E) $R i t=\gamma_{0 \mathrm{t}}+\gamma_{1 \mathrm{t}} \operatorname{Ln}(\mathrm{S} / \mathrm{P})_{\mathrm{it}}+\varepsilon_{\mathrm{it}}$
(F) $R i t=\gamma_{0 \mathrm{t}}+\gamma_{1 \mathrm{t}} \mathrm{DY}_{\mathrm{it}}+\varepsilon_{\mathrm{it}}$
(G) $R i t=\gamma_{0 \mathrm{t}}+\gamma_{1 \mathrm{t}} \beta_{\mathrm{it}}+\gamma_{2 \mathrm{t}} \operatorname{LnM} E_{\mathrm{it}}+\varepsilon_{\mathrm{it}}$
(H) Rit $=\gamma_{0 \mathrm{t}}+\gamma_{1 \mathrm{t}} \beta_{\mathrm{it}}+\gamma_{2 \mathrm{t}} \operatorname{Ln}(\mathrm{BE} / M E)_{\mathrm{it}}+\varepsilon_{\mathrm{it}}$
(I) $R$ it $=\gamma_{0 \mathrm{t}}+\gamma_{1 \mathrm{t}} \mathrm{LnME}_{\text {it }}+\gamma_{2 \mathrm{t}} \operatorname{Ln}(B E / M E)_{\text {it }}+\varepsilon_{\text {it }}$
(J) Rit $=\gamma_{0 \mathrm{t}}+\gamma_{1 \mathrm{t}} \mathrm{LnME}_{\mathrm{it}}+\gamma_{2 \mathrm{t}} \operatorname{Ln}(A / M E)_{\mathrm{it}}+\gamma_{3 \mathrm{t}} \operatorname{Ln}(A / B E)_{\mathrm{it}}+\varepsilon_{\mathrm{it}}$
(K) $R i t=\gamma_{0 \mathrm{t}}+\gamma_{1 \mathrm{t}} \beta_{\mathrm{it}}+\gamma_{2 \mathrm{t}} \operatorname{LnME} E_{\mathrm{it}}+\gamma_{3 \mathrm{t}} \operatorname{Ln}(\mathrm{BE} / M E)_{\mathrm{it}}+\varepsilon_{\mathrm{it}}$
(L) Rit $=\gamma_{0 \mathrm{t}}+\gamma_{1 \mathrm{t}} \mathrm{LnME}_{\mathrm{it}}+\gamma_{2 \mathrm{t}} \operatorname{Ln}(B E / M E)_{\mathrm{it}}+\gamma_{3 \mathrm{t}} \operatorname{Ln}(S / P)_{\mathrm{it}}+\varepsilon_{\mathrm{it}}$

The period 1990-2000 is referred to as a period of economic growth in the Greek market, unlike, the period 2004 to 2011; the Greek stock market clearly shrunk compared to the previous decade. We consider Figure 1 indicative, as well as this diachronically illustrates the value of the ratio "Total Capitalization of the ASE to Gross Domestic Product".

\section{Figure 1}

\section{Total Capitalization to GDP}

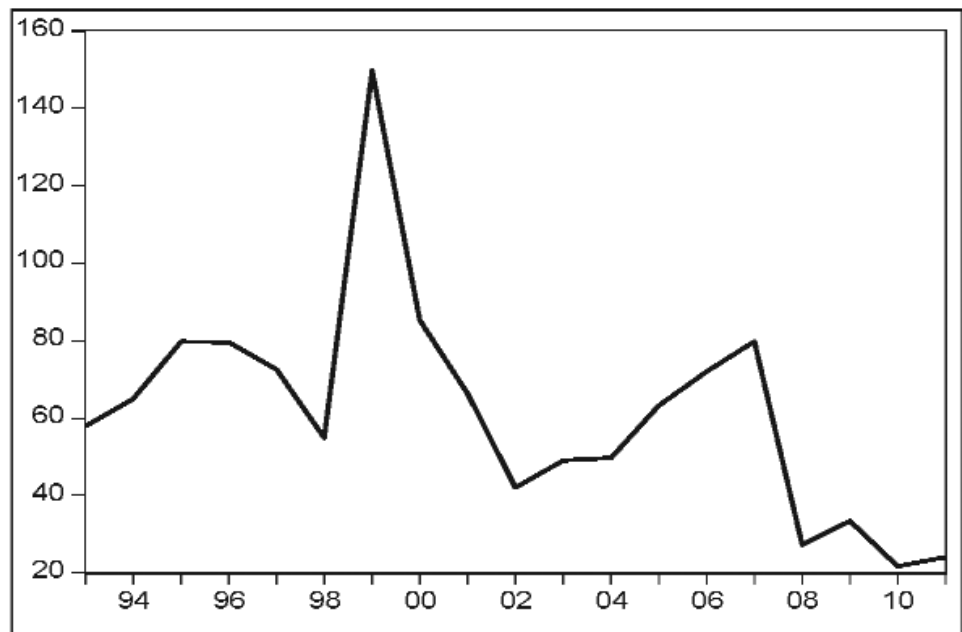


The effect of book to market ratio is tested by the model C. As the result shows, this ratio does not influence on the average stock returns. The value of the average coefficient is $0.013 \%$, with a t-statistic of 1.31 . Although, there seems to be a positive relationship between book to market ratio and average stock returns, we can not say that it is a strong result, because the value of t-statistic is relatively low. This result is the same, when both market beta and book to market ratio are included in regressions (Model $\mathrm{H}$ ). However, when book to market ratio is combined with other explanatory variables, the value of t-statistic is higher than that of the univariate regression (Model I, K, L). The strengthening of the results is likely due to the existence of heteroscedasticity to the individual regressions, which can not be sufficiently reduced by using logarithmic transformations, and by conducting month to month regressions. So, it can be possible to have an overestimated value of the t-statistic, in these models (see Leledakis et al., 2001).

The influence of leverage is investigated in model D. Fama and French (1992) separated the leverage to market leverage $(\mathrm{A} / \mathrm{ME})$ and book leverage $(\mathrm{A} / \mathrm{BE})$ while they proved that the effect of one eliminated the effect of the other. Moreover, they argued that the final influence of leverage is the difference between market and book leverage but this effect is equal to the effect of book to market ratio: $\operatorname{Ln}(B E / M E)=\operatorname{Ln}(A / M E)-\operatorname{Ln}(A / B E)$. The final conclusion of Fama and French (1992) was the leverage and the book to market ratio essentially consists of two equivalent forms in order to explain the "book to market effect".

Our result shows that when leverage is separated into $\mathrm{A} / \mathrm{ME}$ and $\mathrm{A} / \mathrm{BE}$, the book leverage $(\mathrm{A} / \mathrm{BE})$ average coefficient is $-0.040 \%$ with a strong statistical significance $(\mathrm{t}-\mathrm{stat}=-2.78)$ while the market leverage $(\mathrm{A} / \mathrm{ME})$ has an average coefficient $0.011 \%$ but no statistical significance $(\mathrm{t}$-stat $=0.99)$. This means that the book leverage has a strong effect on stocks returns, which are much more powerful than the effect of market leverage, the effect of which is insignificant.

The following three Figures present the relation between the book to market ratio and leverage. Figure 2 presents the monthly coefficients of the variables $\mathrm{A} / \mathrm{ME}$ and $\mathrm{BE} / \mathrm{ME}$ from the univariate regressions. The two variables are identical through time. This is also obvious from the average coefficients on Table 4 (BE/ME: $0.0133 \%$ \& A/ME: $0.011 \%$ ). Figure 3 presents the coefficients of the variables $\mathrm{BE} / \mathrm{ME}$ and $\mathrm{A} / \mathrm{BE}$. We observe an opposite development between book to market ratio and book leverage. The final relation between leverage and book to market ratio is shown in Figure 4, the two effects are similar to one another but the leverage effect is included in the book to market ratio. 
Figure 2

Coefficients of $\mathrm{A} / \mathrm{ME} \& \mathrm{BE} / \mathrm{ME}$

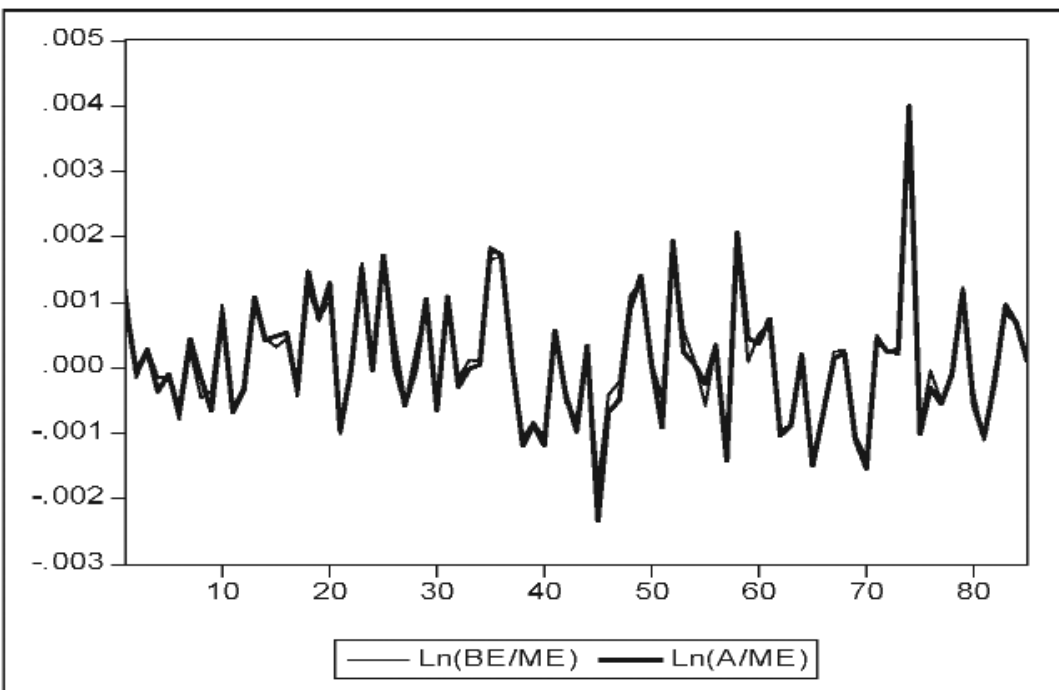

Figure 3

Coefficients of BE/ME \& A/ME

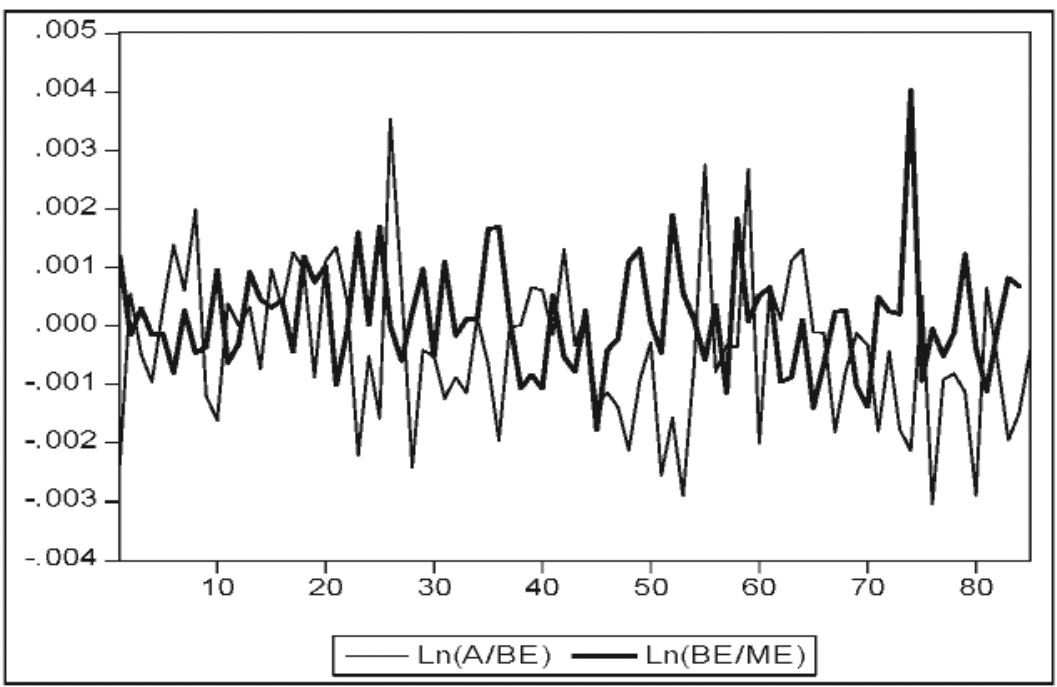


Figure 4

Coefficients of $\mathrm{BE} / \mathrm{ME} \&$ Leverage

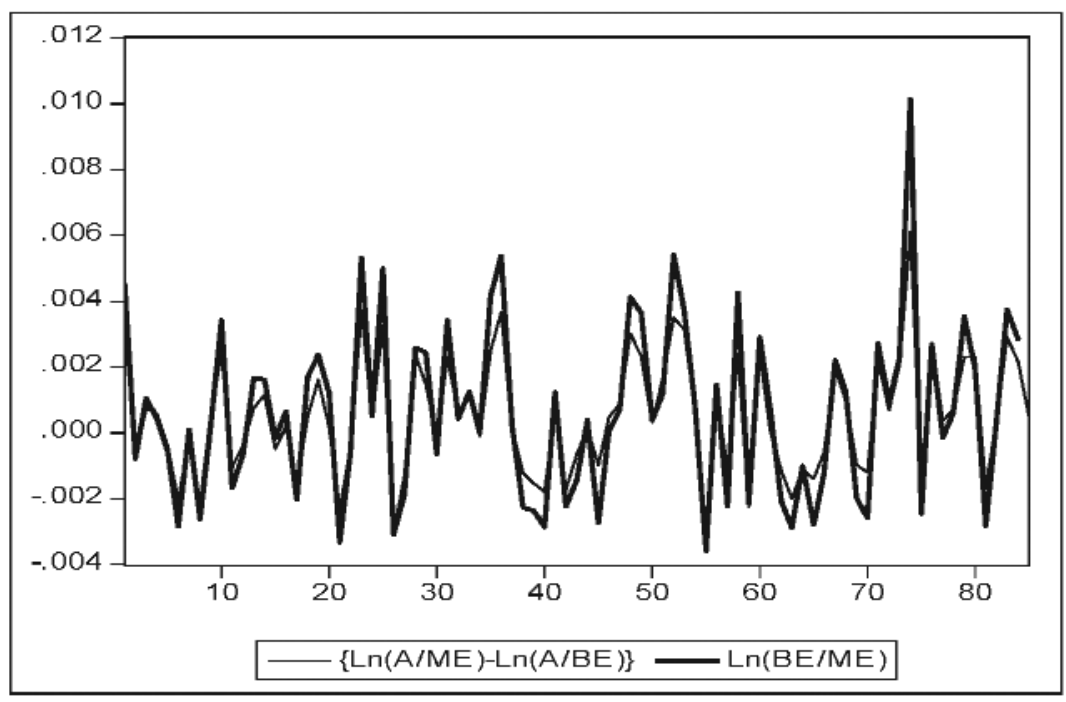

Model I and Model J confirm the above analysis about the relation between the variables of leverage and book to market ratio. The market value (ME) either combined with the variables of leverage (Model J) or with the book to market ratio (Model I), has almost the same average coefficient and t-statistic, $(0.012 \%$, with $\mathrm{t}=1.71 \& 0.011 \%$ with $\mathrm{t}=1.73$, respectively). This observation is a clear indication that between the two variables (leverage and book to market ratio) there is a significant degree of correlation. This result is consistent with Fama and French (1992).

Model (E) tests the relationship between stock returns and sales to price ratio while Model F, the effect of dividend yield. The results of the analysis indicate that both sales to price ratio and dividend yield do not interpret the stock returns. Leledakis et al. (2003) have the same result for the period of July 1990 to June 2000.

In order to test the robustness of the results, the sample period is divided into two non-overlapping and equal sub-periods. The first sub-period begins in June 2004 and finishes in December 2007 while the second sub-period lasts from January 2008 to June 2011. This dichotomy of the sample period into sub-periods serves, as the first sub-period begins with the international and national economies in growth that end in 2007, the year before the economic crisis. The second sub-period includes the recent debt crisis and recession of the Greek economy. The following table includes the average coefficients of the variables of the cross sectional regressions for the two sub-periods. 


\section{Table 5}

Sub-periods average coefficients (\%) for regressions of stock returns with different combinations of variables from July 2004 to June 2011, (t-statistics in parentheses)

\begin{tabular}{|c|c|c|c|c|c|c|c|c|c|}
\hline \multicolumn{10}{|c|}{ Sub-period A: July 2004 - December 2007} \\
\hline & $\gamma_{0}$ & B & In ME & In BE/ME & $\ln \mathrm{A} / \mathrm{ME}$ & $\ln \mathbf{A} / \mathbf{B E}$ & $\ln \mathrm{S} / \mathrm{P}$ & DY & $\operatorname{Avg} R^{2}$ \\
\hline (A) & $0.014 \%$ & $0.024 \%$ & & & & & & & 0.013 \\
\hline t-stat & $(0.42)$ & $(1.36)$ & & & & & & & \\
\hline (B) & $-0.120 \%$ & & $0.009 \%$ & & & & & & 0.027 \\
\hline t-stat & $(-0.64)$ & & $(0.98)$ & & & & & & \\
\hline (C) & $0.041 \%$ & & & $0.020 \%$ & & & & & 0.019 \\
\hline t-stat & $(0.96)$ & & & $(1.69)$ & & & & & \\
\hline (D) & $0.028 \%$ & & & & $0.022 \%$ & $-0.007 \%$ & & & 0.031 \\
\hline t-stat & $(0.72)$ & & & & $(1.71)$ & $(-0.34)$ & & & \\
\hline (E) & $0.037 \%$ & & & & & & $0.011 \%$ & & 0.014 \\
\hline t-stat & $(0.89)$ & & & & & & $(1.25)$ & & \\
\hline (F) & $0.042 \%$ & & & & & & & $0.032 \%$ & 0.009 \\
\hline t-stat & $(0.93)$ & & & & & & & $(0.11)$ & \\
\hline (G) & $-0.237 \%$ & $0.034 \%$ & $0.013 \%$ & & & & & & 0.038 \\
\hline t-stat & $(-1.32)$ & $(1.24)$ & $(1.44)$ & & & & & & \\
\hline (H) & $0.029 \%$ & $0.011 \%$ & & $0.019 \%$ & & & & & 0.029 \\
\hline t-stat & $(0.87)$ & $(0.69)$ & & (1.63) & & & & & \\
\hline (I) & $-0.330 \%$ & & $0.021 \%$ & $0.034 \%$ & & & & & 0.042 \\
\hline t-stat & $(-1.65)$ & & $(2.06)$ & $(2.71)$ & & & & & \\
\hline$(\mathrm{J})$ & $-0.356 \%$ & & $0.021 \%$ & & $0.037 \%$ & $-0.022 \%$ & & & 0.054 \\
\hline t-stat & $(-1.84)$ & & $(2.15)$ & & $(2.85)$ & $(-0.99)$ & & & \\
\hline$(\mathrm{K})$ & $-0.384 \%$ & $0.022 \%$ & $0.022 \%$ & $0.032 \%$ & & & & & 0.052 \\
\hline t-stat & $(-2.00)$ & $(1.46)$ & $(2.22)$ & $(2.46)$ & & & & & \\
\hline (L) & $-0.335 \%$ & & $0.021 \%$ & $0.034 \%$ & & & $0.002 \%$ & & 0.050 \\
\hline t-stat & $(-1.68)$ & & $(2.08)$ & $(2.38)$ & & & $(0.18)$ & & \\
\hline \multicolumn{10}{|c|}{ Sub-period B: January 2008 - June 2011} \\
\hline & $\gamma_{0}$ & B & In ME & In BE/ME & $\ln \mathrm{A} / \mathrm{ME}$ & $\ln \mathbf{A} / \mathbf{B E}$ & $\ln \mathrm{S} / \mathrm{P}$ & DY & $\operatorname{Avg} R^{2}$ \\
\hline (A) & $-0.105 \%$ & $-0.062 \%$ & & & & & & & 0.030 \\
\hline t-stat & $(-2.29)$ & $(-1.24)$ & & & & & & & \\
\hline (B) & $-0.142 \%$ & & $-0.001 \%$ & & & & & & 0.015 \\
\hline t-stat & $(-0.92)$ & & $(-0.12)$ & & & & & & \\
\hline$(\mathrm{C})$ & $-0.160 \%$ & & & $0.006 \%$ & & & & & 0.015 \\
\hline t-stat & $(-2.36)$ & & & $(0.38)$ & & & & & \\
\hline
\end{tabular}

(to be continued) 


\begin{tabular}{|c|c|c|c|c|c|c|c|c|c|}
\hline (D) & $-0.089 \%$ & & & & $-0.000 \%$ & $-0.073 \%$ & & & 0.030 \\
\hline t-stat & $(-1.40)$ & & & & $(-0.03)$ & $(-3.59)$ & & & \\
\hline (E) & $-0.156 \%$ & & & & & & $-0.010 \%$ & & 0.018 \\
\hline t-stat & $(-2.32)$ & & & & & & $(-0.76)$ & & \\
\hline (F) & $-0.171 \%$ & & & & & & & $0.382 \%$ & 0.007 \\
\hline t-stat & $(-2.43)$ & & & & & & & $(1.00)$ & \\
\hline (G) & $-0.058 \%$ & $-0.060 \%$ & $-0.003 \%$ & & & & & & 0.046 \\
\hline t-stat & $(-0.38)$ & $(-1.17)$ & $(-0.31)$ & & & & & & \\
\hline (H) & $-0.106 \%$ & $-0.061 \%$ & & $0.013 \%$ & & & & & 0.043 \\
\hline t-stat & $(-2.34)$ & $(-1.22)$ & & $(0.84)$ & & & & & \\
\hline (I) & $-0.186 \%$ & & $0.001 \%$ & $0.008 \%$ & & & & & 0.026 \\
\hline t-stat & $(-1.35)$ & & $(0.18)$ & $(0.46)$ & & & & & \\
\hline (J) & $-0.042 \%$ & & $0.003 \%$ & & $-0.005 \%$ & $-0.072 \%$ & & & 0.042 \\
\hline t-stat & $(-0.29)$ & & $(0.27)$ & & $(-0.24)$ & $(-3.64)$ & & & \\
\hline (K) & $-0.163 \%$ & $-0.068 \%$ & $0.004 \%$ & $0.018 \%$ & & & & & 0.051 \\
\hline t-stat & $(-1.15)$ & $(-1.37)$ & $(0.47)$ & $(1.21)$ & & & & & \\
\hline (L) & $-0.161 \%$ & & $0.000 \%$ & $0.019 \%$ & & & $-0.018 \%$ & & 0.040 \\
\hline t-stat & $(-1.17)$ & & $(0.06)$ & $(1.22)$ & & & $(-1.40)$ & & \\
\hline
\end{tabular}

Examination of the sub-periods shows that market beta is not a factor with explanatory power for the average cross sectional stock returns. This result is the same with that of the entire sample period. The size (ME) and book to market ratio $(\mathrm{BE} / \mathrm{ME})$ in the first sub-period, when combined with other variables, are statistically significant (models I, J, K, L) but does not apply when testing the second sub-period. The lack of significance of size and book to market ratio in the second sub-period, points out the need to conduct these analyses over a sufficiently long time frame to allow for persistent effects to predominate. The practical implication is that these results are more helpful for medium-to long-term investment strategies than for short-term purposes (Leledakis et al., 2001). For other variables, the results of the sub-periods are consistent with those of the whole period.

\section{Conclusions}

In this study, we investigated the explanatory power of the market beta and the effect of firm-specific variables in the cross sectional average stock returns that were listed on the Athens Stock Exchange for the period July 2004 - June 2011. Our study focused on the portfolio analysis, in which portfolios are formed on a key variable in order to identify relationships that may exist between variables and average stock returns. In the second stage, we conducted monthly cross sectional regressions with a view to estimate the effect of the variables. 
The main conclusion from this study is that the market beta is not a factor with significant explanatory power on the average cross sectional returns. This result is consistent with previous literature (Fama and French, 1992), also the same results were found by Leledakis et al. (2003) on the ASE.

During the examination period, the book leverage, i.e. assets to book value ratio, is the only factor that can explain the average stock returns. This result is considered to be clear evidence that investors in the ASE support their decisions based on fundamental data and not on market data, such as the market value or the book to market ratio, due to the volatility of the market, which increases the uncertainty of investors.

The absence of the size effect, that Leledakis et al. (2003) had identified in the ASE on the previous decade (1990-2000), may be due to the existence of frictions in the market, which on the evaluation period either did not exist or have changed. Greece joined the euro area on 1 January 2001 and in the same year the ASE officially was included in the Morgan Stanley Capital International index (MSCI). These events de facto caused structural changes in the market's function and perhaps some improvements to the market's frictions. A further conclusion could be similar to Schert (2002) and Chou et al. (2004), who noted that such "anomalies" are likely to exist but even if they do exist in the period that they were identified, investors with their actions eliminate these effects in order to benefit from this market behavior and so the market becomes more efficient (or less inefficient).

The practical implication of the results for the portfolio formation and performance evaluation by investors is that patterns do not exist in the markets, which someone can follow in order to win. Such effects may have persisted for some years but in no way there is guarantee that they will persist in the future.

\section{Acknowledgements}

I warmly thank Professor Costas Siriopoulos, of the University of Patras and Professor George Leledakis, of the Athens University of Economics and Business, for their valuable remarks and comments.

Any errors and omissions should be charged to the author. 


\section{Notes}

1. See for example, Fama, E. F. and French, K. R. (2004), "The capital Asset Pricing Model: Theory and Evidence".

2. We have chosen to use monthly instead of either daily or weekly returns so as to avoid the short -term noise effect. On the other hand, the choice of a greater time period, for example year, could cause error in measurements as a great bulk of information could have been lost.

3. Conducting statistical tests on portfolios that are formed based on a variable classification creates potential statistical errors, which are due to the way data is acquired (data-snooping bias), see Lo and MacKinlay, (1990).

4. For empirical application of Fama and MacBeth (1973) can see Fama and French (1992), Chan, Hamao and Lakonishok (1991).

5. As the multicolinearity problem we performed tests of VIF and TOL, (Siriopoulos and Filippas 2010, in greek). We do not find any such problem in all monthly regression.

\section{References}

Banz, R. W., 1981. The relationship between return and market value of common stocks. Journal of Financial Economics. 9, 3-18.

Barbee, W. C., Jr., Mukherji, S. and Raines, G., 1996. Do Sales-Price and Debt-Equity Explain Stock Returns Better Than Book-Market and Firm Size? Financial Analysts Journal. 52,2 (March/April):56-60.

Basu, S., 1983. The relationship between earnings' yield, market value, and return for NYSE common stocks: Further evidence. Journal of Financial Economics. 12, 129-156.

Bhandari, L. C., 1988. Dept/equity ratio and expected common stock returns: Empirical evidence. Journal of Finance. 43, 507-28.

Black, F., 1993. Beta and return. Journal of Portfolio Management. 20(Fall), 8-18.

Black, F., Jensen, M. C. and Scholes, M., 1972. The Capital Asset Pricing Model: Some Empirical Tests. Studies in the Theory of Capital Markets (Ed. M. C. Jensen), Praeger, New York.

Chan, L. K. C., Hamao and Lakonishok, J., 1991. Fundamentals and stocks returns in Japan. Journal of Finance. 46, 1739-1789.

Chou, P. H., Chou, R. K., and Wang, J. S., 2004. On the Cross -section of expected Stock Returns, Fama- French ten years later. Finance Letters 2(1), 18-22.

Daniel, K., Titman, S., 1997. Evidence on the characteristics of cross-sectional variation in stock returns. Journal of Finance. 52, 1-33.

Davis, J. L., Fama, E. F., French, K. R., 2000. Characteristics, covariances, and average returns: 1929 to 1997. Journal of Finance. 55, 389-406.

Down, T., Ingram, R., 2000. Beta, size, risk and return. The Journal of financial Research. 13, 3, 245-600.

Fama, E. F. and French, K. R, 1992. The Cross-Section of Expected Stock Returns. Journal of Finance. 47, 427-465.

Fama, E. F. and French, K. R., 2004. The capital Asset Pricing Model: Theory and Evidence. Journal of Economics. 18, 3, 25-46.

Fama, E. F. and French, K. R., 1993. Common Risk Factors in the Returns on Stocks and Bonds. Journal of Financial Economics, 33, 3-56.

Fama, E. F. and MacBeth, J. D., 1973. Risk, return and equilibrium: empirical tests. Journal of Political Economy. 81, 607-36. 
Fama, E. F., and French, K. R., 1998. Value versus growth: The international evidence. Journal of Finance 53, 1975-1999.

Glezakos, M., Mylonas, P., 2004. Size Effect still present in the Athens Stock Exchange. European Research Studies. 7, (3-4), 1-23.

Hou, K., Karolyi, G. A., Kho, B. C., 2011. What fundamental factors drive global stock returns? Review of Financial Studies. May 2011, 1-48.

Hou, K., Moskowitz, T. J., 2005. Market frictions, price delay, and the cross-section of expected returns. Review of Financial Studies. 18, 981-1020.

Kim, D., 1995. The errors in the variables problem in the cross section of expected stock returns. Journal of Finance. 50, 1605-34.

Kim, D., 1997. A reexamination of the firm size, book-to-market, and earnings price in the crosssection of expected stock returns. Journal of Financial and Quantitative Analysis. 32, 463-89.

Knez, P., Ready, M., 1997. On the Robustness of Size and Book-to-Market in Cross-Sectional Regressions. The Journal of Finance, 52, 4, 1355-1382.

Kothari, S. P., Shanken, J. and Sloan, R. G., 1995. Another look at the cross-section of expected stock returns. Journal of Finance. 50, 185-225.

Leledakis, G., Davidson, I., 2001. Are two factors enough? The UK Evidence. Financial Analysts Journal. November/Decemder, 96-105.

Leledakis, G., Davidson, I. and Karathanassis, G., 2003. Cross-sectional estimation of stock returns in small markets: The case of the Athens Stock Exchange. Applied Financial Economics. 13, 413-426.

Litzenberger R. and Ramaswamy, K., 1979. The Effects of personal taxes and dividends on capital assets prices: Theory and empirical evidence. Journal of Financial Economics.7, 163-195.

Lo, A. W. and MacKinlay, A. C., 1990. Data-snooping biases in tests of financial asset pricing models. Review of Financial Studies. 3, 431-67.

Mathijs A. van Dijk, 2011. Is size dead? A review of the size effect in equity returns. Available at: http://papers.ssrn.com/sol3/papers.cfm?abstract_id $=879282$.

Merton, R. C., 1987. A simple model of capital market equilibrium with incomplete information. Journal of Finance. 42, 483-510.

Reinganum, M. R., 1981. Misspecification of asset pricing: Empirical anomalies based on earnings' yields and market values. Journal of Financial Economics, 9, 19-46.

Roll, R., 1981. A Possible explanation of the Small Firm Effect. Journal of Finance, 36, 19-46.

Rosenberg, B., Reid, K., Lanstein, R., 1985. Persuasive evidence of market inefficiency. Journal of Portfolio Management 11, 9-17.

Schwert, G. W., 1983. Size and stock returns, and other empirical regularities. Journal of financial Economics, 12, 3-12.

Schwert, G. W., 2002. Anomalies and Market Efficiency.

Available at: http://papers.ssrn.com/sol3/papers.cfm?abstract_id $=338080$

Siriopoulos, C., Filippas, D., 2010. Econometric Models and Applications with E-views, publ. Anikoula, Thessaloniki. 